Article

\title{
In Vitro Propagation of Aconitum chasmanthum Stapf Ex Holmes: An Endemic and Critically Endangered Plant Species of the Western Himalaya
}

\author{
Shah Rafiq ${ }^{1}{ }^{(D}$, Nasir Aziz Wagay ${ }^{2}$ (D), Irshad Ahmad Bhat ${ }^{1}$, Zahoor Ahmad Kaloo ${ }^{1}$, Sumaira Rashid ${ }^{3}$, \\ Feng Lin ${ }^{4}\left(\mathbb{D}\right.$, Tarek K Zin El-Abedin ${ }^{5}$, Shabir Hussain Wani ${ }^{6, *} \mathbb{D}$, Eman A. Mahmoud ${ }^{7}$, Khalid F. Almutairi ${ }^{8}$ (D) \\ and Hosam O. Elansary $8, *$ (D)
}

check for updates

Citation: Rafiq, S.; Wagay, N.A.; Bhat, I.A.; Kaloo, Z.A.; Rashid, S.; Lin, F.; El-Abedin, T.K.Z.; Wani, S.H.; Mahmoud, E.A.; Almutairi, K.F.; et al. In Vitro Propagation of Aconitum chasmanthum Stapf Ex Holmes: An Endemic and Critically Endangered Plant Species of the Western Himalaya. Horticulturae 2021, 7, 586. https://doi.org/10.3390/ horticulturae7120586

Academic Editor: Sergio Ruffo Roberto

Received: 16 October 2021 Accepted: 15 December 2021 Published: 17 December 2021

Publisher's Note: MDPI stays neutral with regard to jurisdictional claims in published maps and institutional affiliations.

Copyright: (c) 2021 by the authors. Licensee MDPI, Basel, Switzerland. This article is an open access article distributed under the terms and conditions of the Creative Commons Attribution (CC BY) license (https:/ / creativecommons.org/licenses/by/ $4.0 /)$.
1 Plant Tissue Culture and Research Laboratory, Department of Botany, University of Kashmir, Srinagar 190006, India; shahrafiq.scholar@kashmiruniversity.net (S.R.); bhatirshad.scholar@kashmiruniversity.net (I.A.B.); zkaloo@uok.edu.in (Z.A.K.)

2 Department of Botany, Government Degree College, Baramulla 193101, India; nasir.wagay1989@rediffmail.com

3 Department of Environment Science, University of Kashmir, Srinagar 190006, India; sumaira.scholar@kashmiruniversity.net

4 Department of Plant, Soil and Microbial Sciences, Michigan State University, East Lansing, MI 48824, USA; fenglin@msu.edu

5 Department of Agriculture \& Biosystems Engineering, Faculty of Agriculture (El-Shatby), Alexandria University, Alexandria 21545, Egypt; drtkz60@gmail.com

6 Mountain Research Centre for Field Crops, Sher-e-Kashmir University of Agricultural Sciences and Technology of Kashmir, Anantnag 192101, India

7 Department of Food Industries, Faculty of Agriculture, Damietta University, Damietta 34511, Egypt; emanmail2005@yahoo.com

8 Plant Production Department, College of Food \& Agriculture Sciences, King Saud University, Riyadh 11451, Saudi Arabia; almutairik@ksu.edu.sa

* Correspondence: shabirhwani@skuastkashmir.ac.in (S.H.W.); helansary@ksu.edu.sa (H.O.E.)

Abstract: Aconitum chasmanthum Stapf ex Holmes, a highly valued medicinal plant, is a critically endangered plant species with restricted global distribution. Because there is no published report on the in vitro micropropagation of A. chasmanthum, the present study was undertaken to contribute to the development of an efficient micropropagation protocol for its conservation. Seeds collected from the wild showed enhanced germination after being given a chilling treatment $\left(-4{ }^{\circ} \mathrm{C}\right.$ and $\left.-20^{\circ} \mathrm{C}\right)$ for different durations $\left(10,20,30\right.$ and 40 days). Seeds given a chilling treatment of $-4{ }^{\circ} \mathrm{C}$ for 10 days showed enhanced germination rates of $47.59 \pm 0.53 \%$ with a mean germination time of $10.78 \pm 0.21$ days compared to seeds kept at room temperature when grown in an MS basal medium. Nodes, leaves and stems, taken from 20-40-day-old seedlings, were used as an explant for micropropagation. An MS medium supplemented with different concentrations of cytokinins (BAP, Kn), auxins (2,4-D, NAA), and an additive adenine sulphate were tested for callusing, direct shoot regeneration and rooting. Only nodal explants responded and showed direct multiple shoot regeneration with $7 \pm 0.36$ shoots with an elongation of $5.51 \pm 0.26 \mathrm{~cm}$ in the MS medium supplemented with BAP $0.5 \mathrm{mg} / \mathrm{L}$, and with a response time (RT) of $10.41 \pm 0.51$ days and a percentage culture response of $77.77 \pm 2.77 \%$. Rhizome formation was observed after 8 weeks, with the highest culture response of $36.66 \pm 3.33 \%$ in the MS basal media with an RT of $43.75 \pm 0.50$ days. These rhizomes showed a $60 \%$ germination rate within 2 weeks and developed into plantlets. The present in vitro regeneration protocol could be used for the large-scale propagation and conservation of A. chasmanthum.

Keywords: acclimatization; critically endangered; hardening; micropropagation; plant growth regulators; rhizome; seed germination 


\section{Introduction}

Aconitum chasmanthum Stapf ex Holmes, belonging to the Ranunculaceae family, is the most valuable medicinal plant, and it is widely used in the traditional and folk medicines of several countries in Southeast Asia [1]. It is commonly called Vatsanabha (classical), Atees in Urdu, Banbalang, Mohri, Mohand, Mohand Posh or Mohandgurd locally in Kashmir. It has been determined to be critically endangered by the IUCN [2], with an extremely small range of distribution. It is native to the western Himalaya across Pakistan and India, and is found particularly in the sub-alpine and alpine zones from Chitral and Hazara between the altitude of 2300 and $4300 \mathrm{~m}[3,4]$ to Kashmir and Himachal Pradesh between altitudes of 2100 and $3600 \mathrm{~m}[2,5,6]$. It is a robust biennial herb, with paired, rhizomatous, $3-5 \mathrm{~cm}$ long roots, reaching 60-90 $\mathrm{cm}$ in height [6], and grows from the rhizomatous rootstock. Its taste is slightly bitter, followed by a strong tingling sensation. The chief chemical constituents of the A. chasmanthum root are aconitine, mesaconitine, and hypaconitine and their respective hydrolyzed analogues, called monoester alkaloids, which include benzoylaconine, benzoylmesaconine, and benzoylhypaconine [7]. It is one of the most poisonous plants and its biopotency has been accredited to the diterpenoid alkaloid 'aconitine', which is one of its major isolated diterpenoid alkaloids, while its rhizome has been reported to contain $0.79 \mathrm{mg} / \mathrm{g}$ aconitine [7]. A large number of diterpenoid alkaloids, such as 14-O-Benzoyl-8-ethoxybikhaconine, 14-O-Benzoyl-8-methoxybikhaconine, chasmaconitine, chasmanthinine, 3- $\alpha$ bikhaconine, heteratisine, neoline indaconitine [8-10], chasmanine, homochasmaconitine [11] and heterophyllisine, atidine, atisine, 3- bichaconine, neoline, heteroatisine, aconitine, homochasmanine $[12,13]$, have been extracted from the rhizome of this species.

Rhizomes, after mitigation, are used in several Ayurvedic formulations and homoeopathic systems of medicine and have been traded under the name of 'Vatsanabha' since ancient times. This plant is traditionally used by local people for the treatment of fever, rheumatism, coughs, asthma, and snake bites [14], and its pulverized roots are used as an ointment to cure abscesses and boils after being mixed with butter oil [15]. It has been reported that underground rhizomes possess antifungal, insecticidal, and antibacterial properties [4]. In therapeutic doses, it acts as an appetizer: externally it is applied to reduce pain and inflammation, and it stimulates the tip of sensory nerve fibers when applied by rubbing with oil [16]. The tribals (Gujjars and Bakarwals) of Kashmir Himalaya use the dried rootstock (tuber) as a warming agent for livestock on cold, chilly winter days [17], and also for heart disease, fever, anodyne, anti-inflammatory, tonsillitis, diarrhea, anti-diabetic, neurasthenic, astringent, cold, and cough uses [18-20].

Aconitum chasmanthum faces the onslaught of extinction due to the various threats it faces, especially due to its long period of dormancy ( $>5$ months) owing to its hard seed coat and decreased light availability due to its seed burial under the litter of co-existing species, while snow for prolonged periods (photoblastic nature) also affects its seed germination [17] The seeds are at risk of being swept away by severe rains and snow from their natural environment, thus exposing them to unfavorable environmental conditions. After the germination of dispersed seeds, they face competition with co-existing species, largely affecting their survival rates and abundance [21]. The whole plant is uprooted during collection, resulting in the prevention of blooming and seed production, which encumbers the regeneration of the species. Deforestation, avalanches, grazing and trampling by cattle, over-harvesting, the construction of high-altitude roads, tourism huts, and human settlements have exposed their natural environment to abiotic and biotic disturbances, which has led to the loss of their natural populations [21]. Another potential threat to the species is beetles and aphids, which feed on the floral buds and devour the reproductive part of the plant, further reducing the reproductive potential of the species. Moreover, the species has a very specialized ecological niche that may potentially limit its range of extension and dispersion [21].

In vitro propagation techniques have contributed significantly to the growth of the pharmaceutical industry over the past several decades in a variety of ways, including 
varietal improvement. The use of in vitro techniques for rapid and mass propagation offers possibilities for the 'recovery' of endangered species, thus reducing the risk of extinction [22]. Though in vitro propagation protocols have been developed for other Aconitum species, specifically, A. balfourii [23,24], A. carmichaelii [25], A. heterophyllum [26-29], A. napellus [30], A. noveboracense [30] A. nagarum [31], A. violaceum [32,33], and A. ferox [34], no such attempt has been made for $A$. chasmanthum. Considering its critically endangered status and high medicinal value, the present study is focused on developing an efficient micropropagation protocol for the large-scale propagation of $A$. chasmanthum.

\section{Materials and Methods}

\subsection{Plant Material Collection}

Seeds of A. chasmanthum were collected from Razdhan Pass, Jammu and Kashmir, India $\left(34^{\circ} 33^{\prime} 66.0^{\prime \prime} \mathrm{N}\right.$ and $\left.74^{\circ} 38^{\prime} 19.8^{\prime \prime} \mathrm{E}\right)$ at $3270 \mathrm{~m}$ asl in September 2018.

\subsection{Chemicals}

An MS (Murashige and Skoog [35]) medium, containing the plant growth regulators 2,4-dichlorophenoxyacetic acid (2,4-D), indole-butyric acid (IBA), indole-3-acetic acid (IAA), 6-benzylaminopurine (BAP), kinetin (Kn), 1-napthaleneacetic acid (NAA), and an additive adenine sulphate (AdS), were purchased from HiMedia, India. The surface sterilants, including mercuric chloride and sodium hypochlorite, and sucrose were also purchased from HiMedia, India, while agar (plant agar) was purchased from Sigma Aldrich, India.

\subsection{Seed Germination}

The collected seeds were washed under running tap water, surface sterilized with $0.1 \%(w / v)$ mercuric chloride for 8-10 min, followed by washing 3-5 times with sterile (autoclaved, double-distilled) water. These seeds were then dried by putting in folds of sterile filter papers and later given chilling treatments (cold scarification) at $-4{ }^{\circ} \mathrm{C}$ and $-20^{\circ} \mathrm{C}$ for $10,20,30$ and 40 days. Then, they were inoculated into an MS basal medium that contained $0.8 \%(w / v)$ agar and sucrose $(3 \% w / v)$. The sterilized seeds were inoculated in $30 \mathrm{~mL}$ borosilicate glass culture vials and incubated at $25 \pm 2{ }^{\circ} \mathrm{C}$ with $55 \%$ humidity for a $12 \mathrm{~h}$ photoperiod $\left(42-60 \mu \mathrm{mol} \mathrm{m} \mathrm{m}^{-2} \mathrm{~s}^{-1}\right)$ in a plant growth chamber. Three seeds were inoculated per vial, and 7 vials were used for each treatment. The observations were made concerning each non-contaminated seed (experimental unit). Another set of surfacesterilized seeds ( 20 seeds in each block with 3 replicates) were sown in pots containing garden soil, sand, and vermicompost at the ratio of 1:1:1. Pots (each pot contained 4 seeds) were kept in the greenhouse at $25^{\circ} \mathrm{C}$ and watered regularly. After 10 days, the seeds started germinating and were monitored on regular basis. The data was recorded and the mean germination time (MGT) in days was calculated according to Darrudi et al. [36], using the equation:

$$
M G T=\frac{\sum(n \times D)}{N}
$$

where ' $n$ ' is the number of germinated seeds between recording intervals, ' $D$ ' is the number of days since the beginning of the test, and ' $N$ ' is the total number of germinated seeds in the treatment at the end of the experiment.

The seed germination rate was calculated using the equation:

$$
\text { \%Seed germination }=(n / N) \times 100
$$

where ' $n$ ' is the total number of germinated seeds and ' $N$ ' is the number of seeds used at the beginning of the experiment.

\subsection{Explant Preparation and Establishment of In Vitro Shoot Cultures}

Leaves, stems, petioles, and nodes of 20-40-day-old seedlings germinated in an MS medium and garden soil and rhizomes (full and cuttings) collected from the wild were 
inoculated into an MS medium that contained different concentrations and combinations of plant growth regulators. Only nodal explants were responsive, and thus only they were utilized for further studies. The explants were washed for about $2 \mathrm{~h}$ under running tap water, surface sterilized with mercuric chloride $0.01 \%(w / v)$ for $5-8 \mathrm{~min}$ and $2 \%$ sodium hypochlorite $(v / v)$ for $8-10 \mathrm{~min}$, followed by $3-5$ washes with sterile water. Sodium hypochlorite was found to be the most effective sterilant. To initiate micropropagation, the sterile explants were cultured in an MS medium in borosilicate culture flasks ( $150 \mathrm{~mL}$, containing $50 \mathrm{~mL}$ media) containing different concentrations $(0.5-2.5 \mathrm{mg} / \mathrm{L})$ of different cytokinins, including BAP and $\mathrm{Kn}$, and auxins, such as NAA and 2,4-D, as well as an additive, AdS (5-25 mg/L), with $3 \%$ sucrose for the initiation and establishment of in vitro cultures. All the media were solidified with $0.8 \%$ agar and the $\mathrm{pH}$ was adjusted to $5.8 \pm 0.02$ before autoclaving at $121^{\circ} \mathrm{C}$. Cultures were maintained at $25 \pm 2{ }^{\circ} \mathrm{C}$ in a $16 / 8 \mathrm{~h}$ light/dark cycle on racks fitted with cool fluorescent tubes (Philips, India $40 \mathrm{~W} ; 42.0$ and $60.0 \mu \mathrm{mol} \mathrm{m}^{-2} \mathrm{~s}^{-1}$ irradiance inside and outside the culture flasks, respectively) and $60 \%$ $\mathrm{RH}$ (relative humidity). The experiment was repeated at least three times with a total of 12 replicates per treatment (each replicate represents one explant).

\subsection{In Vitro Rooting}

Multiple shoots obtained from nodal explants in vitro, as well as shoots obtained from seedlings grown in garden soil, were tested for rooting. For this purpose, the individual micro-shoots (4-5 cm long) were excised carefully and transferred to glass culture flasks $(150 \mathrm{~mL})$ containing $50 \mathrm{~mL}$ MS medium of different strengths (MS basal and half-strength basal medium) either alone or fortified with various concentrations of IBA (0.5-2.5 mg/L), IAA (0.5-2.5 mg/L), and $\mathrm{Kn}(0.5-2.5 \mathrm{mg} / \mathrm{L})$. Micro-shoots were also transferred to White's medium, which was fortified with IBA, IAA, and $\mathrm{Kn}$ in the concentration range of $0.5-2.5 \mathrm{mg} / \mathrm{L}$ for rooting.

\subsection{In Vitro Rhizome Formation}

Nodal explants that were responsive to the direct multiple shoot induction into the MS media that had been augmented with BAP, 2,4-D and AdS were also tested for in vitro rhizome formation. For this purpose, the above said responsive nodal explants were transferred to or sub-cultured in $150 \mathrm{~mL}$ culture flasks with 10 flasks per treatment containing $50 \mathrm{~mL}$ MS basal media and MS media fortified with BAP, 2,4-D, IBA, IAA, and $\mathrm{Kn}$ in the concentration range of $0.5-2.5 \mathrm{mg} / \mathrm{L}$ and were maintained under controlled conditions in the culture room. Data were subsequently recorded.

\subsection{Germination of Rhizome: Hardening and Acclimatization of Germinated Plantlets}

A chilling treatment at $-4{ }^{\circ} \mathrm{C}$ was applied to the previously generated in vitro rhizomes for a week, after which they were carefully removed from the culture flasks, and washed with sterile water to remove the adhered gelling agent. These rhizomes were then placed in pots containing sterilized garden soil, vermicompost, and sand (1:1:1). These plants were maintained at $23 \pm 2{ }^{\circ} \mathrm{C}$ temperature with $50-60 \%$ relative humidity and a $16 / 8 \mathrm{~h}$ (light/dark) photoperiod, and were provided with diffuse light $\left(42-60 \mu \mathrm{mol} \mathrm{m}^{-2}\right.$ $\mathrm{s}^{-1}$ ) and watered regularly. The germination rate was recorded, and germinated rhizomes (well-developed plantlets with leaves) were then transferred to the Kashmir University Botanical Garden (KUBG) after 3 weeks, and were kept in shade with frequent watering. The morphological data, including the height of plantlets, the number of leaves produced, and survival data, were recorded.

\subsection{Experimental Design and Statistical Analysis}

The treatments reported and compared in each table were evaluated in parallel studies, with statistical analyses performed individually for each treatment. The significance, analysis of variance, and significant differences between treatments were evaluated using two-way ANOVA for seed germination and one-way ANOVA for the rest of the data. The 
Duncan multiple range test (DMRT) was used to determine significant differences between means at $p \leq 0.05$ using SPSS ver. 23 (IBM Corp. Released 2015. IBM SPSS Statistics for Windows, Version 23.0. Armonk, NY, USA: IBM Corp.). Results are shown as mean \pm SEM (standard error mean) for every experiment.

\section{Results}

\subsection{Seed Germination}

Seeds exhibited better germination with the $-4{ }^{\circ} \mathrm{C}$ chilling treatment. The seeds of A. chasmanthum that were subjected to the chilling treatment showed higher germination rates than the seeds maintained at room temperature. The seed germination rate was better in seeds pretreated with the $-4{ }^{\circ} \mathrm{C}$ chilling treatment and placed in an MS medium than seeds which were given the chilling treatment of $-20^{\circ} \mathrm{C}$ and placed in an MS basal medium, as well as the seeds given the chilling treatment at $-4{ }^{\circ} \mathrm{C}$ or $-20^{\circ} \mathrm{C}$ and sown in garden soil. In the MS medium, the seed germination rate was recorded as the highest $(47.59 \pm 0.53 \%)$ with a mean germination time (MGT) of $10.78 \pm 0.21$ days when given the chilling treatment of $-4{ }^{\circ} \mathrm{C}$ for 10 days (Table 1, Figure 1a). However, seeds sown in garden soil had the highest seed germination rate of 24.04 \pm 0.24 with an MGT of $11.88 \pm 0.15$ days with the chilling treatment of $-4{ }^{\circ} \mathrm{C}$ for 10 days (Table 1 , Figure $1 \mathrm{~b}$ ). For control purposes, seeds kept at room temperature were sown in both PGR-free MS media and garden soil, and they showed little difference in the germination rate (Table 2). Seedlings germinated in MS media were poorly developed, and could produce hardly two to three nodes upon subculturing into $50 \mathrm{~mL}$ culture vials. They also survived for $3-4$ weeks. While the seedlings germinated in garden soil were much more vigorous and produced a large number of nodes (five to eight) and survived for more than 2-3 months, no flowering was observed in them.

Table 1. Effect of different chilling treatments on seed germination in MS basal medium and garden soil (garden soil, sand, and vermicompost at $1: 1: 1)$.

\begin{tabular}{ccccc}
\hline $\begin{array}{c}\text { Chilling Treatment } \\
\text { (Temp.) }\end{array}$ & $\begin{array}{c}\text { Chilling Treatment } \\
\text { (Days) }\end{array}$ & Germinating Medium & $\begin{array}{c}\text { Mean Germination Time } \\
\text { (Days, Mean } \pm \text { SEM) }\end{array}$ & Percentage Germination \\
\hline Control MS & - & MS Basal & $12.76 \pm 0.34^{\mathrm{c}}$ & $10.32 \pm 0.29^{\mathrm{a}}$ \\
$-4^{\circ} \mathrm{C}$ & 10 & MS Basal & $10.78 \pm 0.21^{\mathrm{a}}$ & $47.59 \pm 0.53^{\mathrm{h}}$ \\
$-4^{\circ} \mathrm{C}$ & 20 & MS Basal & $12.41 \pm 0.49^{\mathrm{b}}$ & $42.35 \pm 0.49^{\mathrm{g}}$ \\
$-4^{\circ} \mathrm{C}$ & 30 & MS Basal & $15.15 \pm 0.37^{\mathrm{d}}$ & $37.55 \pm 0.71^{\mathrm{f}}$ \\
$-4^{\circ} \mathrm{C}$ & 40 & MS Basal & $15.92 \pm 0.27^{\mathrm{e}}$ & $35.94 \pm 0.38^{\mathrm{e}}$ \\
$-20^{\circ} \mathrm{C}$ & 10 & MS Basal & $13.97 \pm 0.62^{\mathrm{bc}}$ & $34.74 \pm 0.85^{\mathrm{f}}$ \\
$-20^{\circ} \mathrm{C}$ & MS Basal & $14.84 \pm 0.26^{\mathrm{bc}}$ & $31.33 \pm 0.27^{\mathrm{d}}$ \\
$-20^{\circ} \mathrm{C}$ & 30 & MS Basal & $15.25 \pm 0.19^{\mathrm{d}}$ & $28.22 \pm 0.45^{\mathrm{c}}$ \\
$-20^{\circ} \mathrm{C}$ & 40 & MS Basal & $15.91 \pm 0.32^{\mathrm{e}}$ & $24.57 \pm 0.46^{\mathrm{b}}$ \\
Soil control & - & Garden soil & $14.50 \pm 0.44^{\mathrm{c}}$ & $10.05 \pm 0.25^{\mathrm{a}}$ \\
$-4^{\circ} \mathrm{C}$ & Garden soil & $11.88 \pm 0.15^{\mathrm{a}}$ & $24.04 \pm 0.24^{\mathrm{h}}$ \\
$-4^{\circ} \mathrm{C}$ & Garden soil & $13.29 \pm 0.36^{\mathrm{b}}$ & $20.80 \pm 0.26^{\mathrm{g}}$ \\
$-4^{\circ} \mathrm{C}$ & Garden soil & $15.16 \pm 0.45^{\mathrm{d}}$ & $18.48 \pm 0.51^{\mathrm{f}}$ \\
$-4^{\circ} \mathrm{C}$ & 20 & Garden soil & $16.29 \pm 0.23^{\mathrm{e}}$ & $14.91 \pm 0.37^{\mathrm{e}}$ \\
$-20^{\circ} \mathrm{C}$ & 30 & Garden soil & $11.94 \pm 0.2^{\mathrm{bc}}$ & $20.12 \pm 0.14^{\mathrm{f}}$ \\
$-20^{\circ} \mathrm{C}$ & 40 & Garden soil & $12.25 \pm 0.21^{\mathrm{bc}}$ & $17.55 \pm 0.58^{\mathrm{d}}$ \\
$-20^{\circ} \mathrm{C}$ & 10 & Garden soil & $15.78 \pm 0.26^{\mathrm{d}}$ & $14.00 \pm 0.3^{\mathrm{c}}$ \\
$-20^{\circ} \mathrm{C}$ & 20 & Garden soil & $17.05 \pm 0.2^{\mathrm{e}}$ & $12.10 \pm 0.26^{\mathrm{b}}$ \\
\hline
\end{tabular}



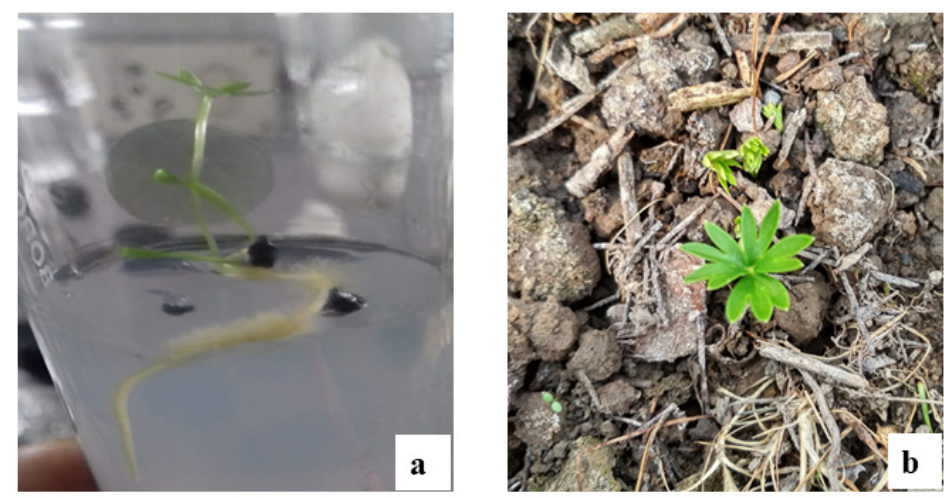

Figure 1. Seed germination in Aconitum chasmanthum Stapf ex Holmes: (a) seed germination in MS basal medium; (b) seed germination in garden soil.

Table 2. Effect of different plant growth regulators (PGRs) on direct shoot induction, shoot length (mean \pm SEM), shoot number (mean $\pm \mathrm{SEM}$ ) and percentage response (mean $\pm \mathrm{SEM}$ ) from the nodal explants.

\begin{tabular}{|c|c|c|c|c|c|c|}
\hline \multicolumn{3}{|c|}{ PGR (mg/L) } & \multirow{2}{*}{$\begin{array}{l}\text { Response Time (Days, } \\
\text { Mean } \pm \text { SEM) }\end{array}$} & \multirow{2}{*}{$\begin{array}{l}\text { Shoot Length (cm, } \\
\text { Mean } \pm \text { SEM) }\end{array}$} & \multirow{2}{*}{$\begin{array}{l}\text { Shoot Number } \\
\text { (Mean } \pm \text { SEM) }\end{array}$} & \multirow{2}{*}{$\begin{array}{l}\text { Percentage Response } \\
\quad(\text { Mean } \pm \text { SEM) }\end{array}$} \\
\hline BAP & 2,4-D & AdS & & & & \\
\hline- & - & - & $0.00 \pm 0.00^{\mathrm{a}}$ & $0.00 \pm 0.00^{a}$ & $0.00 \pm 0.00^{\mathrm{a}}$ & $0.00 \pm 0.00^{\mathrm{a}}$ \\
\hline 0.5 & - & - & $10.41 \pm 0.51^{b}$ & $5.51 \pm 0.26^{c}$ & $7.0 \pm 0.36^{\mathrm{e}}$ & $77.77 \pm 2.77^{\mathrm{d}}$ \\
\hline 1.0 & - & - & $12.13 \pm 0.46^{c}$ & $5.1 \pm 0.76^{c}$ & $5.8 \pm 0.41^{\mathrm{d}}$ & $69.44 \pm 2.78^{\mathrm{cd}}$ \\
\hline 1.5 & - & - & $13.49 \pm 0.46^{\mathrm{cd}}$ & $4.3 \pm 0.16^{b}$ & $4.8 \pm 0.29^{c}$ & $61.1 \pm 2.77^{\mathrm{cd}}$ \\
\hline 2.0 & - & - & $14.36 \pm 0.51^{\mathrm{d}}$ & $3.87 \pm 0.15^{b}$ & $4.2 \pm 0.32^{b}$ & $50 \pm 4.81^{\mathrm{b}}$ \\
\hline 2.5 & - & - & $17.18 \pm 0.3^{\mathrm{e}}$ & $3.86 \pm 0.18^{b}$ & $3.6 \pm 0.33^{b}$ & $44.44 \pm 2.78^{b}$ \\
\hline- & 0.5 & - & $14.58 \pm 0.33^{b}$ & $5.25 \pm 0.14^{c}$ & $4.2 \pm 0.2^{\mathrm{d}}$ & $72.22 \pm 2.78^{c}$ \\
\hline- & 1.0 & - & $17.54 \pm 0.36^{c}$ & $4.93 \pm 0.07^{b}$ & $3.7 \pm 0.21 \mathrm{~cd}$ & $66.66 \pm 4.81^{c}$ \\
\hline - & 1.5 & - & $21.72 \pm 0.27^{e}$ & $4.37 \pm 0.2^{b}$ & $3.3 \pm 0.22 \mathrm{bc}$ & $61.1 \pm 2.77^{c}$ \\
\hline- & 2.0 & - & $20.12 \pm 0.18^{d}$ & $4.27 \pm 0.22^{b}$ & $3.0 \pm 0.21^{b}$ & $47.21 \pm 5.55^{b}$ \\
\hline - & 2.5 & - & $20.87 \pm 0.23^{\text {de }}$ & $4.22 \pm 0.14^{b}$ & $2.9 \pm 0.23^{b}$ & $38.88 \pm 2.77^{\mathrm{b}}$ \\
\hline- & - & 5.0 & $18.84 \pm 0.25^{b}$ & $7.93 \pm 0.39^{c}$ & $3.0 \pm 0.21^{\mathrm{c}}$ & $58.33 \pm 4.8^{c}$ \\
\hline- & - & 10 & $20.78 \pm 0.27^{c}$ & $8.11 \pm 0.42^{c}$ & $3.6 \pm 0.16^{c}$ & $69.44 \pm 2.78^{d}$ \\
\hline- & - & 15 & $22.18 \pm 0.42^{\mathrm{cd}}$ & $6.1 \pm 0.22^{b}$ & $2.8 \pm 0.24$ bc & $55.33 \pm 4.8^{c}$ \\
\hline - & - & 20 & $23.25 \pm 0.55^{\mathrm{d}}$ & $6.6 \pm 0.33^{b}$ & $2.6 \pm 0.22^{b c}$ & $41.55 \pm 4.81^{b}$ \\
\hline- & - & 25 & $25.86 \pm 0.64^{\mathrm{e}}$ & $6.09 \pm 0.14^{b}$ & $2.3 \pm 0.15^{b}$ & $35.88 \pm 2.72^{b}$ \\
\hline
\end{tabular}

The data were recorded for up to 6 weeks. The data represent the mean value \pm SEM (standard error mean) and were found to be statistically operative and significant according to Duncan's multiple range test (DMRT) at $p \leq 0.05$. Mean \pm SEM followed by the different letters within each column are significantly different according to DMRT (one-way ANOVA was performed within the same hormone) at $p \leq$ 0.05. Abbreviations: 2,4-D: 2,4-dichlorophenoxyacetic acid; BAP: 6-benzylaminopurine; and AdS: Adenine sulphate.

The data were recorded for up to 4 weeks. The data represent the mean value $\pm \mathrm{SEM}$ (standard error mean) and were found to be statistically operative and significant through DMRT at $p \leq 0.05$. The mean values with the same superscript(s) within columns are not significantly different according to DMRT (two-way ANOVA) at $p \leq 0.05$.

\subsection{Multiple Shoot Induction}

Shoot induction and multiplication was only seen in nodal explants among the various explants utilized in the current study (leaves, stems, petiole, rhizome, and nodes). There was no evidence of callusing. Although shoot induction was not observed in MS basal media without PGR, MS medium supplemented with BAP (0.5-2.5 mg/L), 2,4-D $(0.5-2.5 \mathrm{mg} / \mathrm{L})$ and AdS $(5-25 \mathrm{mg} / \mathrm{L})$ resulted in shoot induction from the second week, while Kn and NAA were not responsive during the present study. The highest shoot proliferation in terms of shoot number $(\mathrm{SN})$, shoot length (SL) in centimeters $(\mathrm{cm})$, and percentage response (PR) with minimum response time (RT) in days was observed in the case of MS media supplemented with BAP $0.5 \mathrm{mg} / \mathrm{L}$, with an RT of $10.41 \pm 0.51$ days, an $\mathrm{SN}$ of $7 \pm 0.36$, SL of $5.51 \pm 0.26 \mathrm{~cm}$ and a percentage response of $77.77 \pm 2.77 \%$ respectively (Table 2, Figure 2a). Explants taken from seedlings germinated on garden soil were more responsive than in vitro-germinated seedlings and provided the bulk of the explants for multiple shoot induction. 

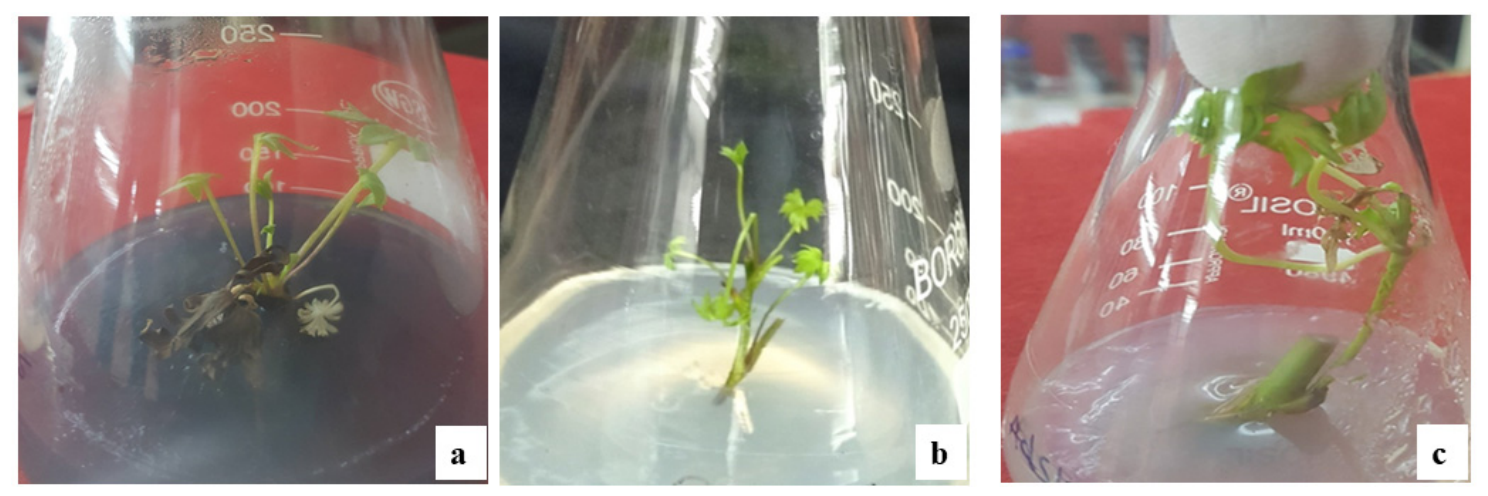

Figure 2. Direct shoot regeneration from nodal explants Aconitum chasmanthum Stapf ex Holmes: (a) direct shoot regeneration from nodal explants in MS medium supplemented with BAP $(0.5 \mathrm{mg} / \mathrm{L})$; (b) direct shoot regeneration from nodal explants in MS medium supplemented with 2,4-D (0.5 mg/L); (c) direct shoot regeneration from nodal explants in MS medium supplemented with AdS (10 mg/L).

The effect of different auxins, such as 2,4-D and NAA, was also observed for direct shoot regeneration in nodal explants, but only 2,4-D responded to in vitro growth conditions. The highest direct shoot regeneration in terms of RT, SN, SL and PR were observed in the MS media supplemented with 2,4-D (0.5 mg/L), with an MRT of $14.58 \pm 0.33$ days, an SN of $4.2 \pm 0.2$, an SL of $5.25 \pm 0.14 \mathrm{~cm}$ and a $72.22 \pm 2.77$ culture response (Table 2, Figure $2 \mathrm{~b}$ ).

The effect of an additive adenine sulphate (AdS) as a nitrogenous base was also observed on direct shooting from nodal explants. The highest multiple direct shoot regeneration was observed in terms of RT, SN, SL and PR on the MS media supplemented with AdS $10 \mathrm{mg} / \mathrm{L}$, with an RT of $20.78 \pm 0.27$ days, an SN of $3.6 \pm 0.16$, SL of $8.11 \pm 0.42 \mathrm{~cm}$ and a $69.44 \pm 2.78 \%$ culture response (Table 2, Figure 2c). In addition to this, the SL was highest in the case of AdS with respect to BAP and 2,4-D during the current study. Though the number of shoots obtained using AdS was much lower in comparison to BAP and 2,4-D, they were more vigorous and longer. During our study, it was found that increasing the concentration of PGRs adversely affected shoot induction in terms of minimum response time, shoot number, shoot length and percentage response.

\subsection{In Vitro Rooting}

Single excised shoots $4-5 \mathrm{~cm}$ in length were placed in MS media with IAA, IBA or $\mathrm{Kn}(0.5-2.5 \mathrm{mg} / \mathrm{L})$ to induce rooting. Root differentiation did not occur at any of the concentrations tested. Instead, shoots remained green for nearly 10 days before the start of senescence. The use of half-strength MS basal medium or White's medium also did not contribute to rooting in vitro.

\subsection{In Vitro Rhizome Formation}

In the present study, in vitro rhizome formation was observed, which started in the cultures after 6 weeks. The highest in vitro rhizome formation in terms of RT and PR was observed in MS basal alone, with an RT of $43.75 \pm 0.50$ days and a $36.66 \pm 3.33 \%$ culture response (Table 3, Figure 3). in vitro rhizome formation was also observed in the MS media supplemented with BAP (0.5-1.5 mg/L). In the MS basal media without PGRs, a maximum of two rhizomes were formed, while in the MS media augmented with BAP, three to five rhizomes were formed. Although the rhizome formation was better in terms of percentage response and mean germination time in the MS basal medium without PGRs, the rhizomes formed in the MS medium augmented with BAP were more vigorous in terms of shoot length and the number of rhizomes formed per explant. 
Table 3. In vitro rhizome formation in A. chasmanthum. Effect of different concentrations of MS basal media and MS media augmented with BAP on in vitro rhizome formation.

\begin{tabular}{cccc}
\hline \multicolumn{2}{c}{ BAP $(\mathbf{m g} / \mathbf{L})$} & Response Time (days, Mean \pm SEM) & Percentage Response \\
\hline MS Basal & - & $43.75 \pm 0.50^{\mathrm{a}}$ & $36.66 \pm 3.33^{\mathrm{b}}$ \\
MS & 0.5 & $50.5 \pm 0.74^{\mathrm{b}}$ & $33.33 \pm 3.33^{\mathrm{ab}}$ \\
MS & 1.0 & $55.91 \pm 0.59^{\mathrm{c}}$ & $26.66 \pm 3.33^{\mathrm{ab}}$ \\
MS & 1.5 & $63.66 \pm 0.66^{\mathrm{d}}$ & $23.33 \pm 3.33^{\mathrm{a}}$ \\
\hline
\end{tabular}

The data were recorded for up to 10 weeks. The data represent the mean value \pm SEM (standard error mean) and were found to be statistically operative and significant according to Duncan's multiple range test (DMRT) at $p \leq 0.05$. Mean \pm SEM followed by the different letters within each column are significantly different according to DMRT (one-way ANOVA) at $p \leq 0.05$.
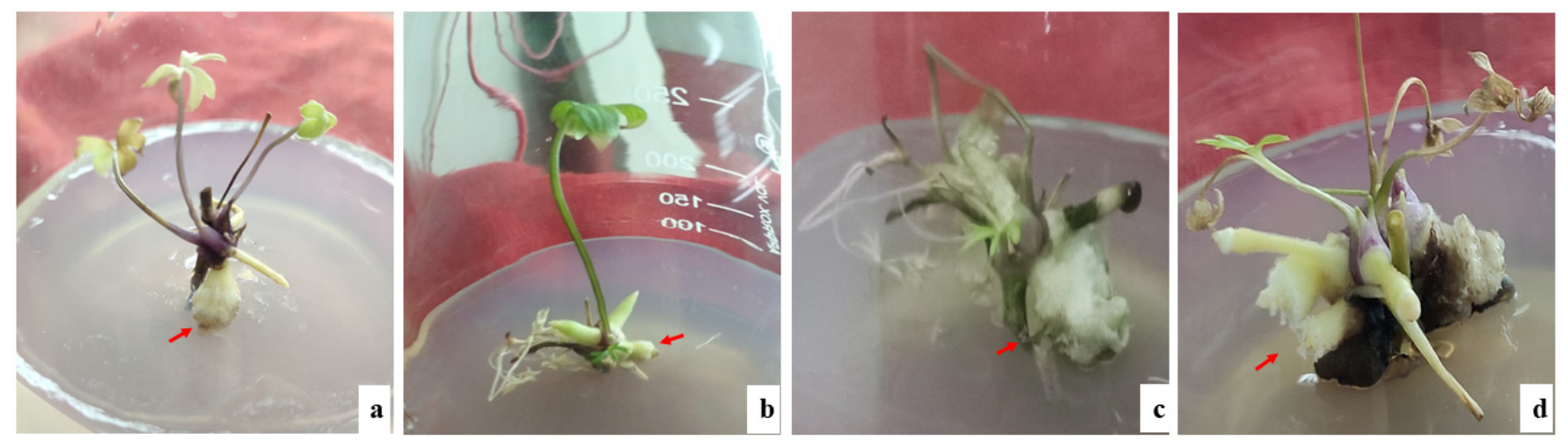

Figure 3. In vitro rhizome formation in Aconitum chasmanthum Stapf ex Holmes: (a) in vitro rhizome formation in MS Basal media; (b) in vitro rhizome formation in MS media supplemented with BAP $(0.5 \mathrm{mg} / \mathrm{L})$; (c) in vitro rhizome formation in MS media supplemented with BAP $(1.0 \mathrm{mg} / \mathrm{L}) ;(\mathbf{d})$ in vitro rhizome formation in MS media supplemented with BAP $(1.5 \mathrm{mg} / \mathrm{L})$.

\subsection{Acclimatization and Hardening of Plantlets}

Transplanted in vitro rhizomes germinated within 2 weeks. Among these in vitrogerminated rhizomes, $60 \%$ resulted in the growth of plantlets. After 3 weeks in a controlled environment, the plantlets were transported (transferred) to the Kashmir University Botanical Garden (KUBG), where they were kept in shade and watered daily for 3 days, before being transferred into garden soil from pots and watered regularly. They survived for 4-5 weeks after their transference to KUBG, and these in vitro developed plantlets produced a maximum of 12-14 leaves and grew up to a height of $30 \mathrm{~cm}$ (Table 4, Figure $4)$.

Table 4. Morphological data of hardened plantlets.

\begin{tabular}{ccc}
\hline WEEK & NUMBER OF LEAVES (MEAN \pm SEM) & HEIGHT OF PLANTS (CM, MEAN \pm SEM) \\
\hline 1ST & $1.83 \pm 0.30^{\mathrm{a}}$ & $2.66 \pm 0.33^{\mathrm{a}}$ \\
2ND & $2.83 \pm 0.30^{\mathrm{ab}}$ & $7.83 \pm 0.65^{\mathrm{b}}$ \\
3RD & $3.5 \pm 0.22^{\mathrm{b}}$ & $14.16 \pm 0.74^{\mathrm{c}}$ \\
4TH & $6.16 \pm 0.70^{\mathrm{c}}$ & $17.66^{\mathrm{b}} \pm 0.76^{\mathrm{d}}$ \\
5TH & $9.33 \pm 0.84^{\mathrm{d}}$ & $22.83 \pm 0.74^{\mathrm{e}}$ \\
6TH & $11.16 \pm 0.65^{\mathrm{e}}$ & $26.66 \pm 0.49^{\mathrm{f}}$ \\
7TH & $13.66 \pm 0.66^{\mathrm{f}}$ & $28.5 \pm 0.76^{\mathrm{fg}}$ \\
8TH & $14.33 \pm 0.33^{\mathrm{f}}$ & $30.33 \pm 0.66^{\mathrm{g}}$ \\
\hline
\end{tabular}

The data were recorded for up to 8 weeks. The data (10 replicates) represent the mean value \pm SEM (standard error mean) and were found to be statistically operative and significant according to Duncan's multiple range test (DMRT) at $p \leq 0.05$. Mean \pm SEM followed by the different letters within each column are significantly different according to DMRT (one-way ANOVA) at $p \leq 0.05$. 

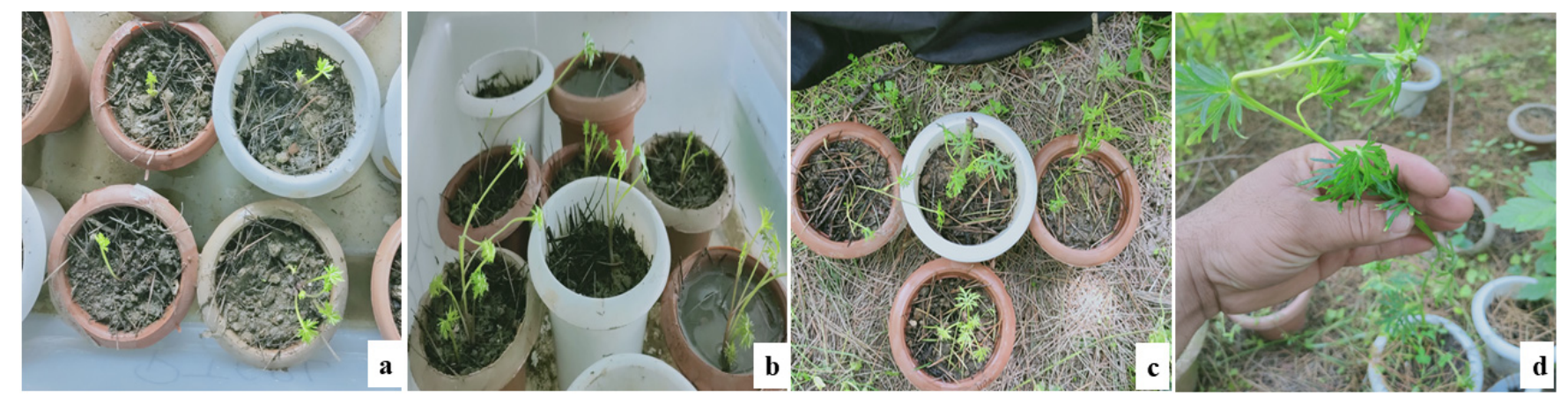

Figure 4. Hardening and acclimatization of in vitro-germinated rhizomes in Aconitum chasmanthum Stapf ex Holmes: (a) 2-week-old germinated rhizomes; (b) 3-week-old germinated rhizomes; (c) 4-week-old germinated rhizomes; (d) 6-week-old germinated rhizomes.

\section{Discussion}

The extraction of many species of the genus Aconitum from their natural habitat has been happening on a massive scale because of their great medicinal properties and other uses. As a result, several species have become rare and are now classified as vulnerable to critically endangered. The easiest and most cost-effective way to conserve a species is through in situ and ex situ conservation [37]. For most species, seed-based multiplication is the most efficient, practical and easy method [38]. Erratic flowering and fruiting in aconites due to severe environmental circumstances results in limited or non-viable seed production [39], and their regeneration through seeds is made difficult due to the absence of superior germplasm and meager seed availability, and some seeds even contain an underdeveloped embryo [40]. Seed germination is low because of the seeds' prolonged dormancy and stiff seed coat [41], which make them sensitive to seed pests and predators [21]. There is also a risk that severe rains and snow might wash seeds away from their native habitat, which could potentially impede their normal development [21]. Breaking dormancy in Ranunculaceae is generally best achieved via (chilling) cold scarification [41-44]. According to Beigh et al. [45], only freezing may increase the seed germination of A. heterophyllum at lower elevations. Chilling-enhanced seed germination in $A$. sinomontanum was reported to be a crucial and prerequisite condition for its germination [46]. Vandelook et al. [47] observed that embryo development and germination in A. lycoctonum occur exclusively at low temperatures (less than $10{ }^{\circ} \mathrm{C}$ ) and that the chilling criterion is not met by $\mathrm{GA}_{3}$. Due to the maturity of seeds during late autumn and winter, $A$. chasmanthum seeds also require chilling to break their dormancy [21]. A. heterophyllum seeds chilled for 30-45 days had a germination rate of 50-60\% [48]. Even in natural settings, seed germination and seedling establishment in A. atrox is rare [49] and has been proven to be poor in several testing situations [50]. Gujree [17] also found that the seeds of $A$. chasmanthum germinated at a rate of $90 \%$ after 20 days of chilling treatment, with an MGT of 13.678 days, while seeds kept at room temperature had a germination rate of $10.66 \pm 1.154$ and an MGT of $22.11 \pm 0.358$ days. These studies suggest that a low temperature is the most important factor in Aconitum sp. germination, which was verified in the current investigation.

Tissue culture provides a new area for conserving the endangered Aconitum sp. since a small quantity of plant material may yield a high number of disease-free propagules that can be reintroduced in their natural habitat, and holds tremendous potential to produce high-grade plant-based medicine [51]. To conserve Aconitum species, tissue culture offers a new age of conservation while contributing to the expansion of genetic databases, increasing the yield and synthesis of active components, secondary metabolites, and other compounds of interest [38].

Our results are very much in conformity with previous studies [52], wherein we observed maximum multiple direct shoot regeneration and elongation in the MS media augmented with BAP $0.25 \mathrm{mg} / \mathrm{L}$. These results also substantiate earlier reports where 
other species of genus Aconitum (A. balfourii and A. heterophyllum) showed multiple shoot induction and proliferation in MS medium containing BAP $[26,28,53]$. During our study, it was found that increasing the BAP concentration adversely affected shoot induction, MRT, MSN, MSL and PR, which was likewise reported for A. balfourii, wherein an increase in BAP in the medium adversely affected the induction and growth of shoots [27].

The role of 2,4-D indirect shoot regeneration has been reported in other studies, either alone or in combination with other hormones, as observed by Doğan [54], Sandhya and Srinath [55] and Hesami and Daneshvar [56]. The relative effectiveness of AdS is least amongst the three PGRs used in this study, which is in accordance with the earlier reports of Syzygium cumini [57] and Agapanthus praecox [58]. Our results are very much in conformity with the previous reports [59-61], which observed maximum in vitro rhizome formation in MS medium fortified with BAP and NAA.

\section{Conclusions}

The present study is the first report describing an in vitro regeneration protocol for the large-scale propagation of $A$. chasmanthum, an endemic and threatened plant. Being a critically endangered plant species, the in vitro regeneration protocol developed herein could be useful for the conservation of $A$. chasmanthum. Moreover, the production of rhizomes in vitro is reported for the first time in the genus Aconitum. In addition, this study can also be further used in the identification of biologically active secondary metabolites from in vitro-derived rhizomes and tissues under controlled conditions and their commercial exploitation.

Author Contributions: Conceptualization, S.R. (Shah Rafiq) and Z.A.K.; methodology, S.R. (Shah Rafiq), Z.A.K. and I.A.B.; software, S.R. (Shah Rafiq), N.A.W. and S.R. (Sumaira Rashid); validation, S.R. (Shah Rafiq), Z.A.K. and S.H.W.; formal analysis, S.R. (Shah Rafiq), Z.A.K. and S.H.W.; investigation, S.R. (Sumaira Rashid), I.A.B. and Z.A.K.; resources, S.R. (Shah Rafiq), I.A.B., Z.A.K. and S.H.W.; data analysis, S.R. (Shah Rafiq), N.A.W., S.R. ( Sumaira Rashid), Z.A.K. and S.H.W.; writingoriginal draft preparation, S.R. (Shah Rafiq), I.A.B., S.R. (Sumaira Rashid), N.A.W., T.K.Z.E.-A., K.F.A. and H.O.E.; writing-review and editing, S.R. (Shah Rafiq), N.A.W., I.A.B., Z.A.K., S.H.W., T.K.Z.E.-A., K.F.A., F.L., E.A.M. and H.O.E.; visualization, S.R. (Shah Rafiq), N.A.W., Z.A.K. and S.H.W.; supervision, S.R. (Shah Rafiq) and Z.A.K.; project administration, S.R. (Shah Rafiq) and Z.A.K.; funding acquisition, T.K.Z.E.-A., K.F.A. and H.O.E. All authors have read and agreed to the published version of the manuscript.

Funding: This research was funded by King Saud University (RSP-2021/118).

Institutional Review Board Statement: Not applicable.

Informed Consent Statement: Not applicable.

Data Availability Statement: Data are available with a request from the first author.

Acknowledgments: The authors extend their deep appreciation to the Researchers Supporting Project (RSP-2021/118), King Saud University, Riyadh, Saudi Arabia.

Conflicts of Interest: The authors declare no conflict of interest.

\section{References}

1. The Ayurvedic Pharmacopoeia of India_Part I, 1st ed.; Ministry of Health and Family Planning, Government of India: New Delhi, India, 2000; pp. 180-182.

2. Ved, D.; Saha, D.; Ravikumar, K.; Haridasan, K. Aconitum Chasmanthum; The IUCN Red List of Threatened Species: E.T50126558A79578539; iucnredlist.org 2015. Available online: https://www.iucnredlist.org/species/50126558/79578539 (accessed on 18 October 2021).

3. Chopra, R.N.; Badhwara, R.L.; Ghosh, S. Poisonous Plants of India; Manager of Publications: Delhi, India, $1949 ;$ p. 104.

4. Anwar, S.; Ahmad, B.; Subhan, M.; Gul, W.; Nazar-ul-Islam. Biological and pharmacological properties of Aconitum chasmanthum. J. Biol. Sci. 2003, 3, 989-993.

5. Dhar, U.; Kachroo, P. Alpine Flora of Kashmir Himalaya; Scientific Publishers: Jodhpur, India, 1983; p. 280.

6. Jabeen, N.; Kozgar, M.I.; Dar, G.H.; Shawl, A.S.; Khan, S. Distribution and Taxonomy of Genus Aconitum in Kashmir: Potent Medicinal Resource of Himalayan Valley. Chiang Mai J. Sci. 2013, 40, 173-186. 
7. Dubey, N.; Dubey, N.; Mehta, R.; Saluja, A. Selective Determination of Aconitine in Polyherbal Oils Containing Aconitum chasmanthum Using High-Performance Thin-Layer Chromatography. J. AOAC Int. 2009, 92, 1617-1621. [CrossRef] [PubMed]

8. Parvez, M.; Gul, W.; Anwar, S. Chasmanthinine. Acta Crystallogr. Sect C Cryst. Struct. Commun. 1998, 54, 125-126. [CrossRef]

9. Achmatowicz, O., Jr.; Tsuda, Y.; Marion, L.; Okamoto, T.; Natsume, M.; Chang, H.H.; Kajima, K. Chasmanine and its structure. Can. J. Chem. 1965, 43, 825-839. [CrossRef]

10. Parvez, M.; Gul, W.; Anwar, S.; Miana, G.A.; Choudhary, M.I. Indaconitine 0.5-acetonitrile solvate. Acta Crystallogr. Sect. C Cryst. Struct. Commun. 1999, 55, 70-72. [CrossRef]

11. Uslu, B.; Lingeman, H.; Ozkan, S.A.; Palit, M.; Dogan-Topal, B. Analytical method development and validation of pharmaceutical analysis using chromatographic techniques. Chromatogr. Res. Int. 2012, 2012, 948129. [CrossRef]

12. Dubey, N.; Dubey, N.; Mehta, R. Development and Validation of Selective High-Performance Liquid Chromatographic Method Using Photodiode Array Detection for Estimation of Aconitine in Polyherbal Ayurvedic Taila Preparations. Chromatogr. Res. Int. 2012, 2012, 157916. [CrossRef]

13. Dar, B.A.; Lone, A.M.; Khan, R.A.; Qurishi, M.A. Studies on Structure Elucidation of Aconitum Alkaloids Using LC-ESI-MS Technique. Am. J. Ethnomed. 2015, 2, 2348-9502.

14. Gujree, G.M.; Nawchoo, I.A.; Wafai, B.A. Meiotic System and Pollination Mechanisms of the Critically Endangered Aconitum chasmanthum Stapf ex Holmes-A Novel Species Endemic to Kashmir Himalayan Region. Int. J. Plant Rep. Biol. $2009,1,153-162$.

15. Rasool, G. Medicinal Plants of the Northern Areas of Pakistan; SAAD Printo Pack: Rawalpindi, Pakistan, 1998 ; pp. $13-15$.

16. Shyaula, S.L.; Phytochemicals, T.U. Processing of Aconitum Species in Nepal. Nepal J. Sci. Technol. 2011, 12, 171-178. [CrossRef]

17. Gujree, G.M. Studies on Reproductive Biology to Develop Conservationn Strategies for Picrorhlza kurrooa Royle ex Benth. and Aconitum chasmanthum Stapf ex Holmes. Ph.D. Thesis, Department of Botany, University of Kashmir, Srinagar, India, 2007.

18. Shinwari, Z.K.; Watanabe, T.; Rehman, M.; Yoshikawa, T. A Pictorial Guide to Medicinal Plants of Pakistan; Kohat University of Science and Technology: Kohat, Pakistan, 2006; Volume 1, pp. 969-8870.

19. Shrikumar, S.; Ravi, T.K. Approaches towards development and promotion of herbal drugs. Pharmacogn. Rev. 2007, 1, 180-184.

20. Khare, C.P. Indian Medicinal Plants; Springer: Berlin, Germany, 2007.

21. Mir, A.H.; Tyub, S.; Kamili, A.N. Ecology, distribution mapping and conservation implications of four critically endangered endemic plants of Kashmir Himalaya. Saudi J. Biol. Sci. 2020, 27, 2380-2389. [CrossRef]

22. Nadeem, M.; Kumar, A.; Nandi, S.K.; Palni, L.M.S. Tissue culture of medicinal plants with particular reference to Kumaun Himalaya. In Proceedings of the Workshop on Himalayan Medicinal Plants Potential and Prospects, Almora, India, 5-7 November 1998.

23. Pandey, H.; Nandi, S.K.; Kumar, A.; Palni, U.T.; Chandra, B.; Palni, L.M.S. In vitro propagation of Aconitum balfourii Stapf; an important aconite of Himalayan alpine. J. Hort. Sci. Biotechnol. 2004, 21, 69-84. [CrossRef]

24. Gondval, M.; Chaturvedi, P.; Gaur, A.K. Thidiazuron-induced high frequency establishment of callus cultures and plantlet regeneration in Aconitum balfourii Stapf.: An Endangered Medicinal Herb of North-West Himalayas. Indian J. Biotechnol. 2016, 15, 251-255.

25. Hatano, K.; Kamura, K.; Shoyama, Y.; Nishioka, I. Clonal multiplication of Aconitum carmichaeli Debx. by tip tissue culture and alkaloid contents of clonally propagated plants. Planta Med. 1988, 54, 152-154. [CrossRef]

26. Giri, A.; Ahuja, P.S.; Kumar, P.V.A. Somatic embryogenesis and plant regeneration from callus culture of Aconitum heterophyllum Wall. Plant Cell Tissue Organ Cult. 1993, 32, 213-218. [CrossRef]

27. Sharma, E.; Gaur, K.; Punetha, H.; Gaur, A.K. In vitro regeneration of Aconitum balfourii stapf: A rare medicinal herb from Himalayan alpine through root explant. Res. J. Med. Plant. 2012, 6, 318-325. [CrossRef]

28. Mahajan, R.; Kapoor, N.; Singh, I. Effect of Growth Regulators on In vitro Cultures of Aconitum heterophyllum: An Endangered Medicinal Plant. Int. J. Pure Appl. Biosci. 2015, 3, 50-55. [CrossRef]

29. Belwal, N.S.; Kamal, B.; Sharma, V.; Gupta, S.; Dobriyal, A.K.; Jadon, V.S. Production of genetically uniform plant from shoot tips of Aconitum heterophyllum Wall. a critically endangerd medicinal herb. J. Hort. Sci. Biotechnol. 2016, 91, 529-535. [CrossRef]

30. Cervelli, R. In vitro propagation of Aconitum noveboracense and Aconitum napellus. Hort. Sci. 1987, 22, $304-305$.

31. Deb, C.R.; Langhu, T. Development of in vitro propagation protocol of Aconitum nagarum Stapf. Plant Cell Biotechnol. Mol. Biol. 2017, 18, 324 .

32. Rawat, J.M.; Agnihotri, R.K.; Nautiyal, S.; Rawat, B.; Chandra, A. In vitro propagation, genetic and secondary metabolite analysis of Aconitum violaceum Jacq.: A threatened medicinal herb. Acta Physiol. Plant 2013, 35, 2589-2599. [CrossRef]

33. Chandra, B. Studies on Propagation, Agrotechnology and Phytochemical Evaluation of Some Alpine Medicinal Plants of Himalayan Region. Ph.D. Thesis, Kumaun University, Nainital, India, 2003; p. 148.

34. Singh, M.; Chettri, A.; Pandey, A.; Sinha, S.; Singh, K.K.; Badola, H.K. In vitro propagation and phytochemical assessment of Aconitum ferox wall: A threatened medicinal plant of Sikkim Himalaya. Proc. Natl. Acad. Sci. India Sect. B Boil. Sci. 2019, 90, 313-321. [CrossRef]

35. Murashige, T.; Skoog, F. A revised medium for rapid growth and bioassays with tobacco cultures. Physiol. Plant. 1962, $15,473-497$. [CrossRef]

36. Darrudi, R.; Hassandokht, M.R.; Nazeri, V. Effects of $\mathrm{KNO}_{3}$ and $\mathrm{CaCl}_{2}$ on seed germination of Rheum khorasanicum B. Baradaran \& A. Jafari. J. Appl. Sci. Res. 2014, 10, 171-175. 
37. Nidhi, S.; Vikas, S.; Barkha, K.; Dobriyal, A.K.; Jadon, V.S. Advancement in research on Aconitum sp. (Ranunculaceae) under different area: A review. Biotechnology 2010, 9, 411-427. [CrossRef]

38. Sharma, R.K.; Sharma, S.; Sharma, S.S. Seed germination behaviour of some medicinal plants of Lahaul and Spiti cold desert (Himachal Pradesh): Implications for conservation and cultivation. Cur. Sci. 2006, 90, 1113-1118.

39. Pandey, H.; Nandi, S.K.; Nadeem, M.; Palni, L.M.S. Chemical stimulation of seed germination in Aconitum heterophyllum Wall and A. balfourii Stapf.: Important Himalayan species of medicinal value. Seed Sci Technol. 2000, 28, 39-48.

40. Nautiyal., B.P.; Nautiyal, M.C.; Khanduri, V.P.; Rawat, N. Floral biology of Aconitum heterophyllum wall: A critically endangered alpine medicinal plant of Himalaya, India. Turk. J. Bot. 2009, 33, 13-20.

41. Frost, C. Embryo development in ripe seeds of Eranthis hiemalis and its relation to giberrallic acid. Physiol. Plant. 1974, 30, 200-205. [CrossRef]

42. Baskin, C.C.; Baskin, J.M. Deep complex morphophysiological dormancy in seeds of the mesic woodland herb Delphinium tricorne (Ranunculaceae). Int. J. Plant Sci. 1994, 155, 738-743. [CrossRef]

43. Walck, J.L.; Baskin, C.C.; Baskin, J.M. Seeds of Thalictrum mirabile (Ranunculaceae) require cold stratification for loss of non-deep simple morphophysiological dormancy. Can. J. Bot. 1999, 77, 1769-1776. [CrossRef]

44. Forbis, T.A.; Floyd, S.K.; DeQueiroz, A. The evolution of embryo size in angiosperms and other seed plants: Implications for the evolution of seed dormancy. Evolution 2002, 56, 2112-2125. [CrossRef]

45. Beigh, S.Y.; Nawchoo, I.A.; Iqbal, M. Cultivation and Conservation of Aconitum heterophyllum: A Critically Endangered Medicinal Herb of the Northwest Himalayas. J. Herbs Spices Med. Plants 2005, 1, 47-56.

46. Dosmann, M.S. Stratification improves and is likely required for germination of Aconitum sinomontanum. Hort. Technol. 2002, 12, 423-425. [CrossRef]

47. Vandelook, F.; Lenaerts, J.; Jozef, A.V.A. The role of temperature in post-dispersal embryo growth and dormancy break in seeds of Aconitum lycoctonum L. Flora-Morphol. Distrib. Funct. Ecol. Plants 2009, 204, 536-542. [CrossRef]

48. Paramanick, D.; Panday, R.; Shukla, S.S.; Sharma, V. Primary pharmacological and other important findings on the medicinal plant "Aconitum heterophyllum" (aruna). J. Pharmacopunct. 2017, $20,89$.

49. Bhadula, S.K.; Singh, A.; Lata, H.; Kuniyal, C.P.; Purohit, A.N. Distribution Pattern, Population Diversity and Propagation of Some High-Altitude Medicinal Herbs from Garhwal Himalaya: Problems and Prospects for Conservation. High Altitudes of the Himalaya II (Biodiversity, Ecology, and Environment); Pangtey, Y.P.S., Ed.; Gyanodaya Prakashan: Nainital, Pakistan, 2002; pp. 389-413.

50. Nautiyal, M.C.; Rawat, A.S.; Bhadula, S.K. Germination in two Aconitum species. Seed Res. 1985, 14, $133-139$.

51. Murch, S.J.; KrishnaRaj, S.; Saxena, P.K. Tryptophan is a precursor for melatonin and serotonin biosynthesis in in vitro regenerated St. John's wort (Hypericum perforatum L. cv. Anthos) plants. Plant Cell Rep. 2000, 19, 698-704. [CrossRef] [PubMed]

52. Jabeen, N.; Shawl, A.S.; Dar, G.H.; Jan, A.; Sultan, P. Callus induction and organogenesis from explants of Aconitum heterophyllum medicinal plant. Biotechnology 2006, 5, 287-291.

53. Watad, A.A.; Kochba, M.; Nissima, A.; Gaba, V. Improvement of Aconitum napellus micropropagation by liquid culture on floating membrane rafts. Plant Cell Rep. 1995, 14, 345-348. [CrossRef]

54. Doğan, M. In vitro rapid propagation of an aquatic plant Pogostemon erectus (Dalzell) Kuntze. Anatol. J. Bot. 2019, 3, 1-6. [CrossRef]

55. Sandhya, H.; Srinath, R. Role of growth regulators on in vitro callus induction and direct regeneration in Physalis minima Linn. Int. Lett. Nat. Sci. 2015, 44, 38-44. [CrossRef]

56. Hesami, M.; Daneshvar, M.H. In vitro adventitious shoot regeneration through direct and indirect organogenesis from seedlingderived hypocotyl segments of Ficus religiosa L.: An important medicinal plant. Hort. Sci. 2018, 53, 55-61. [CrossRef]

57. Naaz, A.; Shahzad, A.; Anis, M. Effect of adenine sulphate interaction on growth and development of shoot regeneration and inhibition of shoot tip necrosis under in vitro condition in adult Syzygium cumini L.-A multipurpose tree. App. Biochem. Biotech. 2014, 173, 90-102. [CrossRef] [PubMed]

58. Baskaran, P.; van Staden, J. Rapid in vitro micropropagation of Agapanthus praecox. S. Afr. J. Bot. 2013, 86, 46-50. [CrossRef]

59. Qadir, J.; Singh, S.; Kour, S.; Kaloo, Z.A.; Ganai, B.A. In vitro Propagation of Polygonatum verticillatum All. A Threatened Medicinal Herb through Seed Explant. J. Sci. Res. 2020, 64, 111-117. [CrossRef]

60. Roy, J.; Banerjee, N. Rhizome and shoot development during in vitro propagation of Geodorum densiflorum (Lam.) Schltr. Sci. Hortic. 2002, 94, 181-192. [CrossRef]

61. Chen, Y.; Liu, X.; Liu, Y. In vitro plant regeneration from the immature seeds of Cymbidium faberi. Plant Cell Tissue Organ Cult. 2005, 81, 247-251. [CrossRef] 